\title{
Using the analytic hierarchy process to evaluate sustainability factors in watershed planning and management
}

With increasing population growth and economic development, water resources have faced environmental pollution and ecological deterioration. Sustainable watershed management and planning has emerged as an approach to address these problems. Following the international agreements on watershed protection, Turkey has initiated fundamental modifications in the watershed management and planning process. However, sustainable management of water resources involves various economic, social, and ecological dimensions, and it is not a straightforward process. This study ranks sustainability indicators in terms of their importance in water resource resilience. The analytic hierarchy process is utilized to weight the sustainability factors in planning water resources and watersheds.
Considering the different opinions experts may have, two groups of respondents (i.e., academics and professionals) were chosen to evaluate the factors. The results showed degrees of correspondence and contradictions among the respondents' perspectives. The groups were similar in prioritizing the social, management, and economic factors, whereas they showed considerable differences in evaluating the land use and ecological factors. The article shows that the conflicting views of various groups of experts should be identified and harmonized in order to develop an evaluation model for watershed and water basin plans.

Keywords: watershed planning, sustainable water management, analytic hierarchy process, Turkey 


\section{Introduction}

Water basins or watersheds are essential sources for water supply, water purification, and flood and erosion control. Rapid urbanization, population growth, and increasing demand for socioeconomic development have increased pressure on freshwater resources and deteriorated wetlands (Kennedy et al., 2012). Furthermore, with facing environmental issues related to water use, water pollution, and climate change, sustainable water management has become one of the most important sustainable development goals (United Nations, 2014). Watershed plans aim to improve the management and implementation of sustainable development programmes for water resources (Chandniha et al., 2014) and they are designed and operated in ways that make the water resources more adaptive, robust, and resilient in the face of an uncertain and changing future (Loucks \& Beek, 2017).

Earlier approaches to sustainable water management have emphasized different development indexes and indicators involving multidimensional economic and environmental aspects (WCED, 1987; Basiago, 1999). According to Brooks et al. (2013), basin management is the process of organizing the use of land and other resources within a basin to provide the desired products or services without adversely affecting soil and water resources. Watershed management includes the allocation of water resources between various users and purposes, choosing between environmental objectives and human needs (Barrow, 1998; Molle, 2006). Loucks and Gladwell (1999) provide criteria for water sustainability, which emphasize the importance of water infrastructure, environmental quality, economics and finance, institutions and society, human health and welfare, as well as planning and technology. Watershed management aims to control or eliminate the water basin related issues such as adverse effects of droughts, floods, and excessive pollution resulting from agricultural activities and imprecise land uses in the water basins as well as enhancing water quality and aquatic ecosystems (Loucks \& Beek, 2017). Mays (2006) introduced seven requirements to ensure the sustainability of water resource systems: a basic water requirement to maintain human health, a basic water requirement to maintain the health of ecosystems, water quality, long-term renewability of water resources, available information on water sources for all sectors, institutional plans to resolve water conflicts, and participatory water-related decision making. However, sustainable river basin planning and management is a complex phenomenon that is interconnected with socioeconomic, ecological, environmental governance, and technological factors (Lal et al., 2001; Crase \& Cooper, 2015; Srinivas et al., 2018).
As a way of integrating various economic, social, and environmental dimensions, the integrated water resource management (IWRM) approach was introduced in the late nineteenth century to ensure the sustainability of water resources (Internet 1; Kharrazi, 2016). It is a process that promotes the coordinated development and management of water, land, and related resources to maximize the resultant economic and social welfare equitably without compromising the sustainability of vital ecosystems (Global Water Partnership, 2000). The IWRM is multidimensional, comprising the sustainability triangle (i.e., the economic, environmental, and social dimensions), legislation and health issues, technique and technology, institutional and political issues, and historical and cultural issues (Thomas \& Durham, 2003).

Another approach that encourages the sustainable development of water systems is water resources vulnerability assessment (WRVA). The vulnerability of water resources is influenced by natural factors (physical and ecological), economic and social dimensions, and water institutions and governance, and its assessment shows how much a water system can be jeopardized by both human activity and natural events. Similarly, WRVA determines the ratio of sensitivity of a water resource to climate change, floods, droughts, water shortage, water pollution, and so on. The more the water resources are damaged by these extreme impacts, the less they can be maintained in the long run. Water resource vulnerability factors can be divided into four groups: physical, economic, social, and environmental factors (Füssel, 2007, cited in Idé et al., 2019). WRVA contributes to understanding water resources characteristics and provides a scientific basis for decision-making related to water resource planning and management (Idé et al., 2019). Two quantitative methods can be used for WRVA: the function method focusing on characteristics of the physical mechanism of water resources vulnerability, and the index method dealing with volume and water quality of water resources (Chen et al., 2018). In the index method of assessment four main steps are identified: selecting, weighting, normalizing, and aggregating factors (Idé et al., 2019).

Considering water sustainability principles, the IWRM and WRVA approaches to watershed or water basin planning and management consist of five areas of planning: ecological planning to preserve wetland, land use and infrastructure planning to establish a suitable land use pattern in the basin (Kirby \& White, 1994), social planning to support social changes and improve living conditions (Keating, 1993; Basiago, 1999), economic planning to maximize the economic benefits obtained from the whole basin (Cox, 1987), and management/ administrative planning to define the institutional structures and the cooperation techniques for the implementation of the plan requirement (Kirby \& White, 1994; Mencio et al., 2010). 
In Turkey, the water needs for the population, agriculture, industrial development, and energy purposes have been increasing since the second half of the twentieth century, which has resulted in a deterioration in water resources. Until the 1980s, only the amount of water was considered in water management. Plans were made for individual uses, and personalized solutions were developed for the problems. In the following years, many laws and regulations have been adopted by competent public bodies to protect water resources and an integrated view on water quality has been growing in water resource management. In addition, Turkey has signed several international agreements and declarations related to water issues on the planning and protection of the water basins located in the country. Since 2005, Turkey has been in accession negotiations with the EU and committed to implementing the Water Framework Directive (adopted in 2000) as the most critical directive addressed under the environmental chapter. This directive highlights both the quantity and quality of water, adopts an integrated and basin-based management approach, and provides a framework for the protection of all water, including streams, coastal waters, surface waters, transitional waters, and groundwater, excluding seas (Bilen, 2008). Therefore, according to the European Water Framework Directive and using the IWRM approach, Turkey has introduced a series of changes and modifications in its watershed management and planning.

It seems that there is an essential need to provide a valuation model of the watershed planning factors that help with achieving an integrated and sustainable planning and management approach in Turkey. There are twenty-five river basins with different geographical, physical, and hydrological characteristics in Turkey. The Ministry of Forestry and Water Affairs, as the primary authority responsible for river basin management, has started preparing basin-based management plans for water body protection since 2013. In these plans, the protection and conservation of surface and groundwater and their chemical, environmental, and physical qualities, as well as water quantity, have been the priority. Turkey has also started to prepare water management plans for drinking water resources, developing provisions and policies for the protection of drinking water resources. Even though noticeable achievements in watershed management have been attained, such as an increase in treatment plants (Turkey Ministry of Development, 2014), administrative cooperation, and proper studies on watershed quality, ecosystem services, and landscape characterization (Tezer et al., 2018), in some other aspects such as public participation, decentralization of administration, water-related policy and regulations, the technology needed for nutrient recycling, and water quality measuring and monitoring, more work is needed. Therefore, this article aims to weight the primary sustainability factors in watershed planning. Furthermore, it analyses and compares the opinions of academics and professionals work- ing at water management institutions on prioritizing the planning factors in watershed management. The results will help to understand the diverse perspectives of the two groups on sustainability factors and discuss the impact that the different academics' preferences in prioritizing planning criteria might have on watershed sustainability.

\section{Methods}

\subsection{Research aims}

The main aim of this study is to define a valuation model for the sustainability indicators in water resource planning and management. It seeks to understand the interrelationship among watershed sustainability variables according to expert perspectives. Considering different perspectives that might emerge among the experts, it is presumed that academics (knowledge holders) and professionals (those with experience in water resource planning and management) have different selections and evaluations. Therefore, before deciding on an evolutionary model of the watershed sustainability criteria, it is necessary to understand the contradictory views that might exist among the experts. This study first determines the main criteria and the indicators through a literature review, and a hierarchy of sustainability factors is defined in terms of SWMP. Then, the determinant factors are evaluated through a quantitative decision-making method: the analytic hierarchy process (AHP). Using this method, the watershed planning factors are weighted by the academics and professionals with knowledge and experience in watershed management. Therefore, three main steps have been followed in this study: determining a hierarchy, weighting the sustainability indicators, and building a questionnaire.

\subsection{Determining a hierarchy}

Basins were determined to be the most significant watershed management unit. A water basin includes the water in rivers, aquifers, and lakes/reservoirs, and covers a mosaic of diverse land uses, including forest, agriculture, suburban, and urban areas. The water basin is not merely a hydrological unit but also a sociopolitical entity that plays a significant role in providing life support services, food, and economic security to the people living in the area (Wani et al., 2008). Basin water is critical for domestic, industrial, and agricultural water consumption (New York State Department of State, 2009). Watershed management and planning affect people and livestock as an integral part of a watershed. In an effort to provide a clear framework for watershed sustainability, this work identifies the primary areas, factors, and subfactors of sustainable watershed management and planning (SWMP; see Figure 1). 


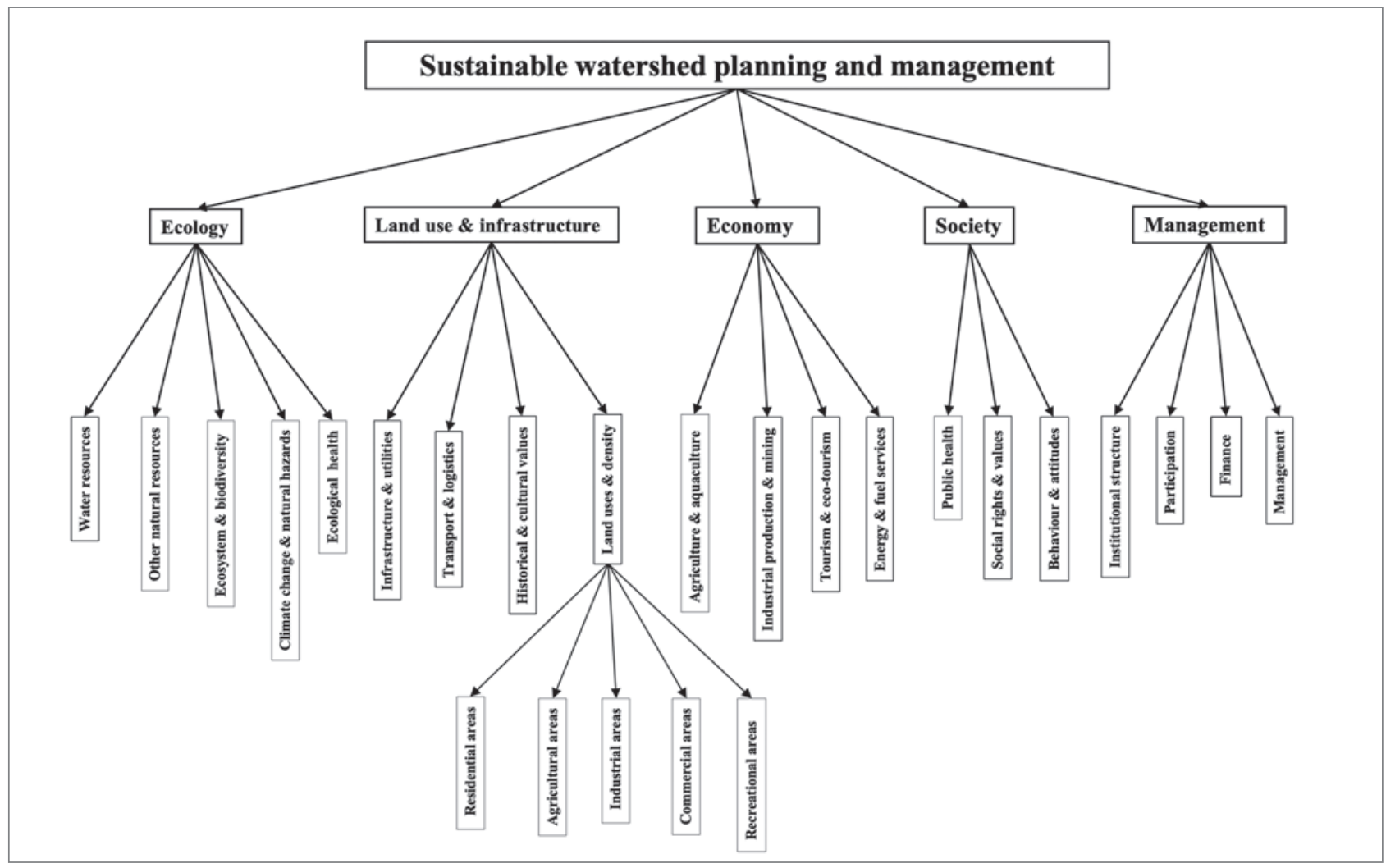

Figure 1: Five main areas with twenty factors and five subfactors of sustainable water resource management and planning (illustration: authors).

Five main dimensions or areas of sustainability were recognized in watershed planning and management:

- Ecology: the current use of the water resource should be managed in a way that maintains critical ecological systems, thereby not compromising use of the same source by future generations of (Jønch-Clausen \& Fugl, 2001). The leading indicators of environmental sustainability identified in this work are water resources (Ouyang, 2012), other natural sources (air, soil, forest), environmental problems including climate change (Räsänen et al., 2017) and natural disasters, ecosystem and biodiversity (Arthington et al., 2009), and ecological health.

- Land use and infrastructure: this area includes the requirements for using the relevant physical sciences and technology in the water basin plans to harmonize the competing interests of various types of land use. Sustainability of the built environment means maintaining human resources and technology for the long term (Yang et al., 2016). This category involves the factors of the reliability, capacity, and rehabilitation rate of infrastructure, transportation and logistics, historical and cultural values, and land uses and construction density.

- Society: population growth and socioeconomic development continuously increase water demands and, thus, extreme water pressure and water shortage risks (Zhou et al., 2018). The fundamental right for all people to have access to water of adequate quantity and quality for the maintenance of human wellbeing must be prioritized through the planning process (Shen et al., 2011). This area consists of provisions that support social changes and better living conditions, which need to understand what people need from the basin. In this area, social rights and values, public health, and the residents' behaviour (their preferences and perceptions) are defined as the primary social factors in the SWMP.

- Economy: This planning dimension intends to maximize the economic benefits obtained from the entire basin and ensure that these costs and benefits are equitably distributed through the water basin planning and management (Cox, 1987). Agriculture and aquaculture development (as primary economic sources); energy production, tourism; industrial and mining development; and commercial activities were identified as significant factors for economic improvement in the entire water basin (Jønch-Clausen \& Fugl, 2001; Shen et al., 2011).

- Management: watershed planning management aims to sustain continuous oversight of water basin planning in the long term. It needs broad engineering responsibilities under the direct supervision of the executive staff (Kirby \& White, 1994). It also involves regulations on the institutional structure (institutional integration and ca- 


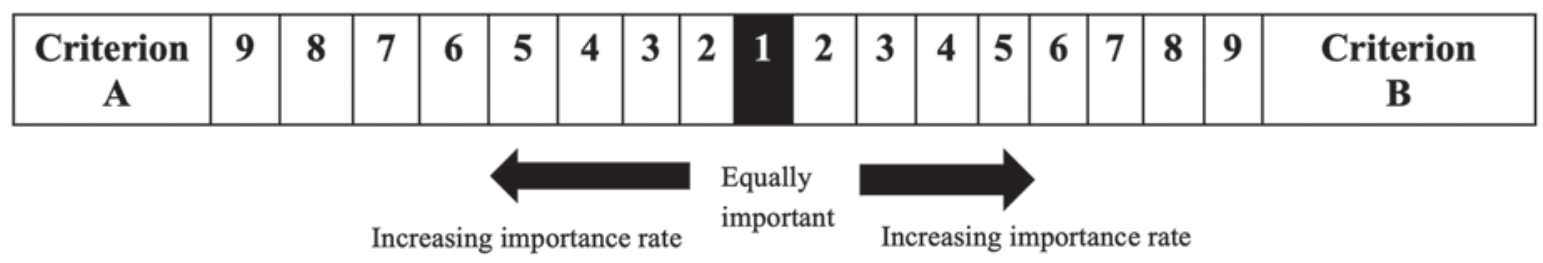

Figure 2: The importance scale in pairwise comparison of two criteria (A and B) (source: Saaty, 1994).

pacity; Dinar et al., 2007; Belay et al., 2010), public and stakeholder participation, management techniques/tools, and finance and governmental funding for water resource planning and management.

\subsection{Weighting the sustainability indicators}

In this study, the AHP was used to understand the interrelationships among the sustainability factors by considering a numerical value for each criterion of SWPM. The AHP, developed by Thomas L. Saaty in the 1970s, is a multiple criteria decision-making approach that provides a better evaluation of subjective criteria of watershed plans. The AHP has been used in various areas to weight the main drivers of urban growth (Thapa \& Murayama, 2010), to prioritize the activities supporting rural development (Oddershede et al., 2007), to determine crucial urban sustainability indicators (Michael et al., 2013), and to evaluate the potential physical characteristics affecting pedestrians' satisfaction with sidewalks (Shafabakhsh et al., 2015). Furthermore, the AHP has been applied in the watershed management process to select a suitable technique for wastewater treatment (Curiel-Esparza et al., 2014), to decide on the responsible manager of the public water service (Ruiz-Villaverde et al., 2013), to choose the suitable alternatives for water resource management (Thungngern et al., 2017), and to analyse the population's perceptions regarding successful water management (Yavuz \& Baycan, 2013). Using AHP, all of the factors of water resources planning in terms of sustainability principles are ranked and pairwise comparisons are made for each criterion that are converted into quantitative numbers. The AHP method in this study is limited to weighting and valuating the planning criteria in order to prioritize them in terms of their importance in the watershed planning and management process.

\subsection{Building a questionnaire}

For pairwise comparison, an online questionnaire was prepared using Google Forms and sent to two groups of professionals and university academics for giving weight and value to the
Table 1: The AHP degree of importance scale.

\begin{tabular}{ll}
\hline Scale & Degree of importance \\
\hline 1 & Equally important \\
\hline 2 & Equally to moderately important \\
\hline 3 & Moderately important \\
\hline 5 & Moderately to strongly important \\
\hline 6 & Strongly important \\
\hline 7 & Strongly to very strongly important \\
\hline 9 & Very strongly important \\
\hline
\end{tabular}

Source: Saaty (1994).

planning dimensions. Therefore, the respondents were limited to individuals that have knowledge or experience in water-related management and planning. In this way, the questionnaire data were obtained from expert judgments on the importance of the planning factors in SWMP. Experts could rate the comparison as equal, moderately strong, strong, very strong, and extremely strong (Table 1). The scale ranges from one to nine, where one implies that the two elements are equally important. On the other hand, nine means that one factor is much more important than the other one in a pairwise matrix (Figure 2).

The online form was sent to the selected individuals, including twenty academics (university teachers) and seventeen experts or professionals working either at the General Directorate of State Hydraulic Works (DSI; 4 persons), Istanbul Water and Sewerage Administration (ISKI; 6 persons), or the Turkish Ministry of Forestry and Water Affairs (7 persons). The university teachers had degrees in one of these areas: urban and regional planning ( 6 persons), landscape architecture (7 persons), forestry engineering (6 persons), or environmental engineering (1 person). The professionals that responded to the questionnaire have either a bachelor's degree $(65 \%)$ or a master's degree $(35 \%)$, specializing in environmental engineering $(50 \%)$, urban planning (40\%), or civil engineering (10\%).

The pairwise comparisons of variables at three levels are organized into a square matrix. The diagonal elements of the matrix 
are 1 and the criterion in the $i$ th row is better than criterion in the $j$ th column if the value of element $(i, j)$ is more than 1 ; otherwise, the criterion in the $j$ th column is better than that in the ith row (Bhushan \& Rai, 2004; Table 2). By calculating the principal eigenvalue of the comparison matrix and normalizing it, the relative importance of the various criteria is obtained. The eigenvector is calculated by multiplying the entries together in each row of the matrix and then taking the $n$th root of that product (Equation 1). The $n$th roots are summed and that sum is used to normalize the eigenvector elements to add to 1.00 (Coyle, 2004). The elements of the normalized eigenvector are termed weights, with regard to the criteria or sub-criteria.

Equation 1: $n$th root of data multiple $=\Pi=\sqrt[n]{a 1 a 2 a 3 a 4 \ldots \ldots .}$. (source: Coyle, 2004).

This study used a software program called Super Decision that is appropriately set up for AHP implementation to calculate the data and provide the matrixes. The software was developed by Thomas L. Saaty and his team in 1996 to help individuals make more rational decisions. This program allowed us to enter the judgments, get results, and obtain the sensitivity rate for the results, which shows the validity of the answers. Therefore, the average of the answers obtained on the questionnaire was entered into the program to get the final weights and normalized values. In this way, comparison matrices and diagrams with an acceptable consistency rate were obtained (the consistency rate according to Saaty should not be more than 0.1 ).

\section{Results}

The average amounts of the answers obtained from the two groups (academics and professionals) were compared and prioritized. The normalized weights are summarized in Table 3, showing the quantitative values considered for each criterion by the two groups of respondents. The results could show brilliant differences and similarities in comparisons of the two groups' perspectives toward the main planning factors of watershed sustainability. In prioritizing four primary dimensions considered for the SWMP, both groups gave the most weight to ecology and water management. The academics chose ecology as the first priority (42\%) whereas the professionals considered water management (36\%) as their most important factor. The academics gave economy the least weight (8\%), but for the professionals, land use and infrastructure was the least important (5\%) comparatively. This may be a reason that there is lack of harmonization between urban planning and watershed management. Society was chosen as the third most important area in watershed sustainability.
In weighting the ecology factors, there is considerable disagreement between the two groups' answers. The academics gave the most weight to ecosystem functions and biodiversity (28\%), and they considered water resources to have the same value as other natural resources. However, in the view of the professionals, water resources (35\%) and then ecological health (26\%) are the most important criteria in the ecology dimension of SWMP. It seems that the professionals had more logical valuations considering water quality issues and current environmental pollution in Turkey's water basins. However, this also shows that they may have less knowledge of the importance of ecological functions and ecosystem cycles in the water system. Analysing the ecosystem services and their functions in the water basins has been recognized as one of the most critical assessments in the planning and management of water areas.

With regard to the land use and infrastructure factors, the academics gave the most weight to land uses and density (51\%). In contrast, the professionals believed that the highest weight should be assigned to historical and cultural values and infrastructure (39\%). Transport was chosen as the least important priority by both groups. The main difference between the two groups' answers is in land uses and density, which was weighted at $14 \%$ by the professionals. In considering the various effects of land uses on the water quality and watershed environment, land use assessment and proper zoning planning are significant parts of any watershed planning and management. Therefore, if decision-makers ignore land use as a planning factor, serious problems in the watersheds or water basins will result.

In weighting the economy factors, the two groups had similar priorities. The choices were agriculture and aquaculture as the first priority, followed by tourism, industrial production and mining, and energy production as the least important criteria. The comparisons show that the professionals put a little more weight (30\%) on tourism than the academics (21\%). It may be because the professionals have more experience and information on the positive effect of tourism activities in the economy of the watershed areas in Turkey. In prioritizing the society factors, the most important values based on the groups' answers were given to public health (50-60\%), then to social rights and values (25-31\%), and finally to behaviour and attitudes (16\%-20\%). These preferences seem reliable, considering the right of public access to safe, clean water and sewers. Even though the criterion of public behaviour was given the least weight, it does not mean this dimension can be ignored in watershed planning projects. Valuating the management factors showed that the two groups have similar perceptions regarding their priorities. They gave the highest weight to management and participation (34-38\%). The academics chose management as the most valuable one, and the professionals 
Table 2: An example of a square matrix of pairwise comparisons among three sub-criteria.

\begin{tabular}{llllll} 
& Sub-criterion 1 & Sub-criterion 2 & Sub-criterion 3 & $\begin{array}{l}\text { nth root of value } \\
\text { product }\end{array}$ & Normalized eigenvector \\
\hline Sub-criterion 1 & 1 & 2 & 8 & 2.51 & 0.594 \\
\hline Sub-criterion 2 & $1 / 2$ & 1 & 6 & 1.44 & 0.341 \\
\hline Sub-criterion 3 & $1 / 8$ & $1 / 6$ & 1 & 0.275 & 0.065 \\
\hline
\end{tabular}

Source: Bhushan \& Rai (2004).

Table 3: Normalized weights and values by category of respondent (i.e., academics and professionals) obtained using the AHP.

\begin{tabular}{|c|c|c|c|c|c|}
\hline Sustainability & Weights & & Factors & Weights & \\
\hline & Academics & Professionals & & Academics & Professionals \\
\hline \multirow{5}{*}{ Ecology } & \multirow{5}{*}{0.418} & \multirow{5}{*}{0.347} & Water resources & 0.220 & 0.349 \\
\hline & & & Other natural resources & 0.215 & 0.142 \\
\hline & & & Ecosystem \& biodiversity & 0.275 & 0.086 \\
\hline & & & Climate change $\&$ natural hazards & 0.200 & 0.167 \\
\hline & & & Ecological health & 0.090 & 0.256 \\
\hline \multirow{4}{*}{$\begin{array}{l}\text { Land use \& infra- } \\
\text { structure }\end{array}$} & \multirow{4}{*}{0.102} & \multirow{4}{*}{0.052} & Infrastructure \& utilities & 0.223 & 0.385 \\
\hline & & & Transport \& logistics & 0.114 & 0.087 \\
\hline & & & Land uses \& density & 0.514 & 0.143 \\
\hline & & & Historical \& cultural values & 0.149 & 0.385 \\
\hline \multirow{4}{*}{ Economy } & \multirow{4}{*}{0.084} & \multirow{4}{*}{0.107} & Agriculture $\&$ aquaculture & 0.578 & 0.528 \\
\hline & & & Industrial production \& mining & 0.112 & 0.081 \\
\hline & & & Tourism \& eco-tourism & 0.213 & 0.300 \\
\hline & & & Energy \& fuel services & 0.097 & 0.091 \\
\hline \multirow{3}{*}{ Society } & \multirow{3}{*}{0.124} & \multirow{3}{*}{0.138} & Social rights \& values & 0.311 & 0.249 \\
\hline & & & Public health & 0.493 & 0.594 \\
\hline & & & Behaviour \& attitudes & 0.196 & 0.157 \\
\hline \multirow{4}{*}{ Management } & \multirow{4}{*}{0.273} & \multirow{4}{*}{0.356} & Institutional structure & 0.205 & 0.213 \\
\hline & & & Participation & 0.288 & 0.376 \\
\hline & & & Finance & 0.169 & 0.137 \\
\hline & & & Management & 0.338 & 0.274 \\
\hline Total & 1 & 1 & & 1 & 1 \\
\hline
\end{tabular}

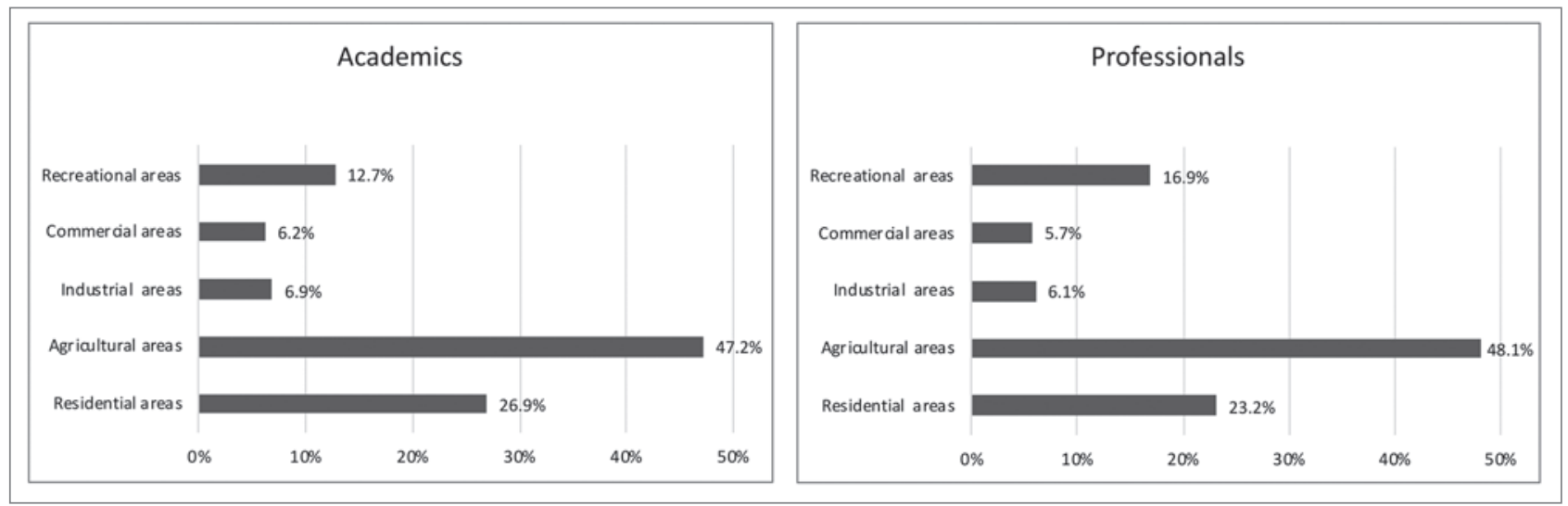

Figure 3: Comparison of the two groups' answers in weighting the land use subfactors in the watershed planning process (illustration: authors). 


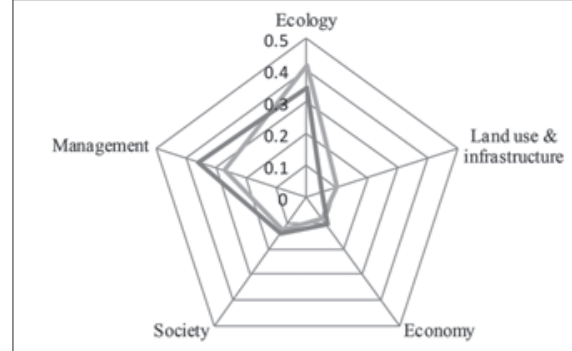

Sustainability dimensions

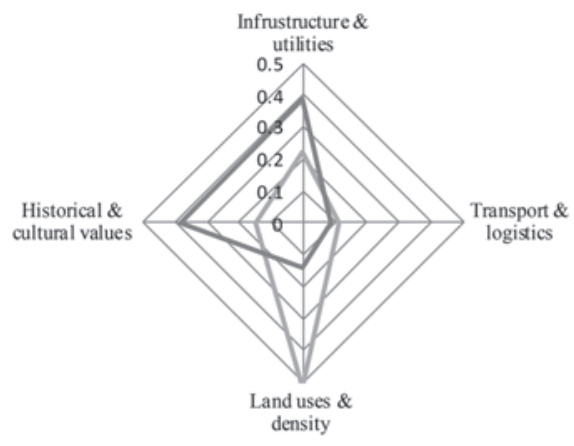

Land use \& infrastructure

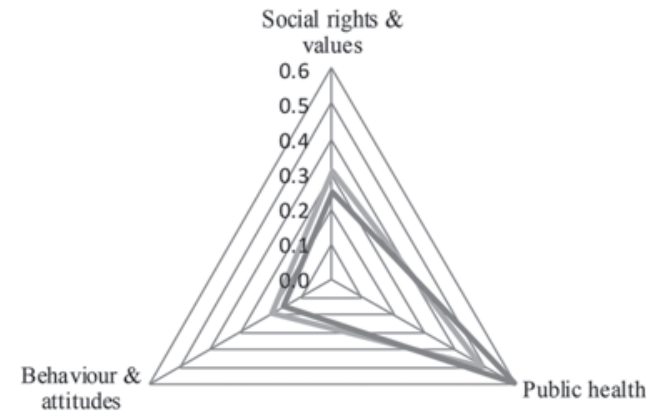

attitudes

\section{Society}

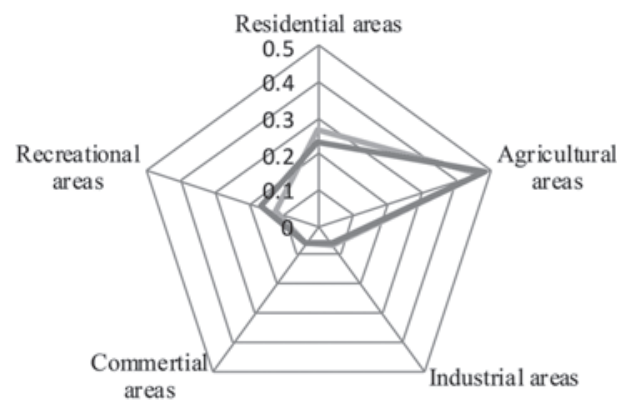

\section{Land use subfactors}

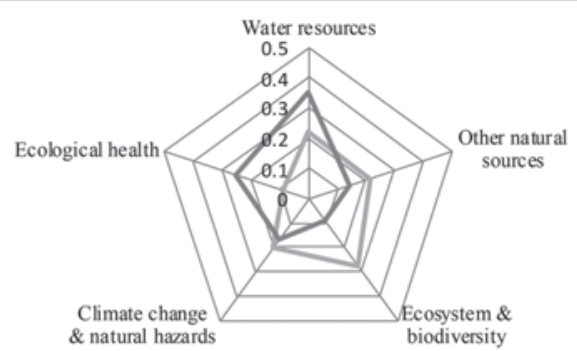

Ecology

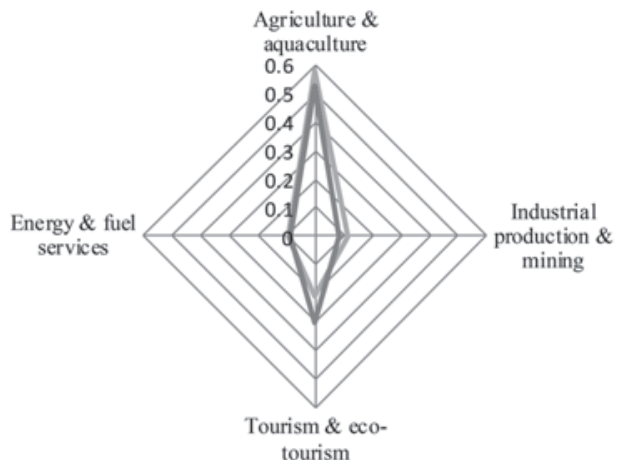

Economy

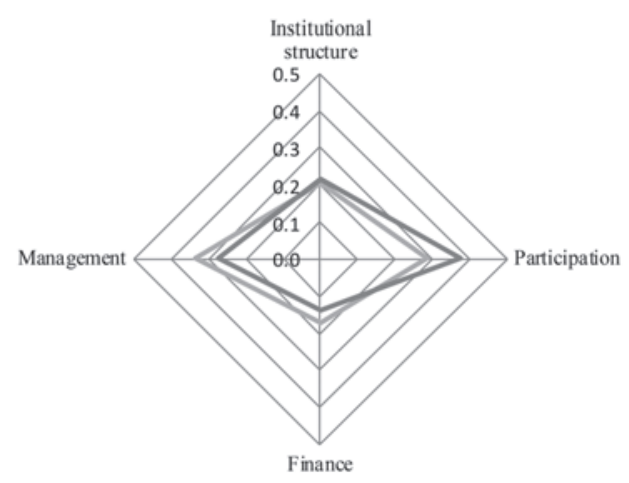

Management

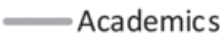

Figure 4: Comparison of the two groups' answers in prioritizing the sustainability criteria of watershed planning and management (illustration: authors). 
assigned the most value to participation. Finance was selected as the factor with the least weight in the SWMP. In evaluating the land use subfactors at the third level of the sustainability hierarchy defined in this research, the two groups agree on the prioritization. As Figure 3 shows, the most weight was given to agricultural areas ( $47-48 \%)$, followed by residential areas $(23-27 \%)$, recreational areas $(13-17 \%)$, and finally commercial $(6 \%)$ and industrial areas $(6-7 \%)$. This choice seems to be suitable because agriculture is the main water-using sector and residential areas are an undeniable part of the water basins. The commercial and industrial areas are mostly restricted by watershed planning provisions due to their negative impacts on the water resources. Recreational uses are partially allowed in some areas of the watershed according to their distance from the water bodies.

This study provides a good example of using the AHP for evaluating sustainability indicators. It employs the AHP to discover the conflicts in watershed management and planning, which may be considered unique in using this method. Watershed planning and management as an interdisciplinary process needs to be integrated with different dimensions and sectors. Therefore, water basin and drinking water management and protection decision-makers are required to have comprehensive knowledge of the related factors and dimensions. These results proved that there are critically different views on the sustainability dimensions among experts, especially in weighting ecology and land use. The professionals considered factors, such as ecosystem functions, infrastructure planning, land use impacts, management, and other natural sources, as less important for the SWMP. The two groups were mostly in agreement on weighting economy and society, water management, and land use factors (Figure 4). Professionals that have inappropriate information on ecosystem functions, land use impacts, management techniques, social and economic requirements, and so on, are not able to provide a sustainable watershed management plan. As a result, in order to define an evaluation model for watershed plans in terms of sustainability principles (which can be applied to all watershed planning and management projects), the views of various types of experts should be harmonized.

\section{Conclusion}

Water resource management and planning are associated with various sustainability factors, including ecology, economy, society, land use, and management. This makes watershed or water resource planning much more complicated, and thus it requires a dynamic, comprehensive, and cooperative approach. The participation and involvement of different groups of water users and stakeholders has been recognized as a critical factor in the decision-making process for watershed management strategies and planning approaches. Cooperation among various local and government agencies and public institutions should be established at the first step of the planning process. However, sometimes there is a great discrepancy in views between professionals and academics, public users and stakeholders, and regional planners and local managers, or even among various groups of experts such as landscape architects, land-use planners, environmentalists, economists, and watershed managers. This discrepancy can occur at all stages of the decision-making process, whereas its effect on preparing the allocation plans for sources of water, land, and finance can be very adverse.

This article shows that there can be a critical contradiction among knowledge holders and decision-makers in some aspects of prioritizing water resource sustainability factors, which may lead to failing to achieve sustainability objectives. It seems that before taking any serious steps toward watershed planning, the gaps among the perspectives of target groups should be identified. Determining the areas of contradicting views can help understand the primary challenges that will appear during the decision-making process, management programming, and implementation efforts. This issue can be eliminated or mitigated through organized meetings, educational workshops, and introductory programmes that allow for discussion among different groups of decision-makers including researchers, university teachers, knowledge holders, and governmental managers. These programmes can be managed for each phase of watershed planning, such as goal determination and prioritization, problem identification, determination of management strategies, suggesting solutions, allocating sources, and so on. At the end of the discussion meetings, it is likely that the participants' perspectives and choices are much more harmonized, which would contribute to the achievement of comprehensive solutions.

Sahar Pouya

Department of Urban and Regional Planning, Graduate School of

Science Engineering and Technology, Istanbul Technical University, Istanbul, Turkey

E-mail: pouya@itu.edu.tr

Handan Turkoglu

Department of Urban and Regional Planning, Faculty of Architecture, Istanbul Technical University, Istanbul, Turkey

E-mail: turkoglu@itu.edu.tr

Umit Arpacioglu

Mimar Sinan Fine Arts University, Faculty of Architecture, Istanbul,

Turkey

E-mail: umitarpacioglu@gmail.com 


\section{References}

Arthington, A. H., Naiman, J. R., McClain, E. M. \& Nilsson, C. (2009) Preserving the biodiversity and ecological services of rivers: New challenges and research opportunities. Freshwater Biology, 55(1), pp. 1-16. DOI: 10.1111/j.1365-2427.2009.02340

Barrow, C. J. (1998) River basin planning and development: A critical review. World Development, 26(1), pp. 171-186.

DOI: $10.1016 /$ S0305-750X(97)10017-1

Basiago, D. (1999) Economic, social, and environmental sustainability in development theory and urban planning practice. The Environmentalist, 19, pp. 145-161.

Belay, A., Semakula, M., Wambura, J. G. \& Jan, L. (2010) SWOT analysis and challenges of Nile Basin Initiative: An integrated water resource management perspective. Chinese Journal of Population Resources and Environment, 8(1), pp. 8-17. DOI: 10.1080/10042857.2010.10684960

Bhushan, N. \& Rai, K. (2004) Strategic decision making: Applying the analytic hierarchy process. London, Springer.

Bilen, Ö. (2008) Turkey's water agenda: Water management and the EU water policy. DSI Official and Financial Affairs Administration, Ankara. Available at: http://ozdenbilen.com/Dosyalar (accessed 30 Mar. 2020).

Brooks, K. N., Folliott, P. F. \& Magner, J. A. (2013) Hydrology and the management of watersheds. 4th ed. Ames, Wiley-Blackwell.

Chandniha, K. S., Kansal, M. L. \& Anvesh, G. (2014) Watershed sustainability index assessment of a watershed in Chhattisgarh, India. Current World Environment, 9(2), pp. 403-411. DOI: 10.12944/CWE.9.2.22

Chen, Y., Feng, Y., Zhang, F. \&Wang, L. (2018) Assessing water resources vulnerability by using a rough set cloud model: A case study of the Huai River Basin, China. Entropy, 21(1), article no. 14. DOI: 10.3390/e21010014

Cox, W. E. (1987) The role of water in socio-economic development. Paris, UNESCO.

Coyle, G. (2004) The analytic hierarchy process (AHP), practical strategy, open access material. London, Pearson Education.

Crase, L. \& Cooper, B. (2015) Politics, socio-economics and water allocations: A note on the limits of integrated water resources management. Australasian Journal of Environmental Management, 22(4), pp. 388-399. DOI: 10.1080/14486563.2015.1041068

Curiel-Esparza, J., Cuenca-Ruiz, A. M., Martin-Utrillas, M. \& Canto-Perello, J. (2014) Selecting a sustainable disinfection technique for wastewater reuse projects. Water, 6(9), pp. 2732-2747. DOI: 10.3390/w6092732

Dinar, A., Kemper, K., Blomquist, W. \& Kurukulasuriya, P. (2007) Whitewater: Decentralization of river basin water resource management. Journal of Policy Modeling, 29, pp. 851-867. DOI: 10.1016/j.jpolmod.2007.06.013

Füssel, H. M. (2007) Vulnerability: A generally applicable conceptual framework for climate change research. Global Environmental Change, 17(2), pp. 155-167. DOI: 10.1016/j.gloenvcha.2006.05.002

Global Water Partnership (2000) Integrated water resources management. TAC Background Papers. No. 4. Stockholm.

Idé K. S., Niandou, S. A., Naimi, M., Chikhaoui M., in Schimmel, K. (2019): Analysis of water resources vulnerability assessment tools. Journal of Agricultural Science and Technology, B 9, str. 69-86. DOI: 10.17265/2161-6264/2019.02.001

Internet 1: https://sustainabledevelopment.un.org/content/documents/ Agenda21.pdf (accessed 30 Mar. 2020).
Jønch-Clausen, T. \& Fugl, J. (2001) Firming up the conceptual basis of integrated water resources management. Water Resources Development, 17(4), pp. 501-510. DOI: 10.1080/07900620120094055

Keating, M. (1993) The Earth Summit's agenda for change: A plain language version of Agenda 21 and the other Rio Agreements. Geneva, Centre for Our Common Future. DOI: 10.1016/0959-3780(94)90026-4

Kennedy, C., Baker, L., Dhakal, S. \& Ramaswami, A. (2012) Sustainable urban systems: An integrated approach. Journal of Industrial Ecology, 16(6). DOI: $10.1111 / j .1530-9290.2012 .00564 . x$

Kharrazi, A. (2016) Evaluating the evolution of the Heihe River basin using the ecological network analysis: Efficiency, resilience, and implications. Science of the Total Environment, 572, pp. 688-696. DOI: 10.1016/j.scitotenv.2016.06.210

Kirby, C. \& White, W. R. (eds.) (1994) Integrated river basin development. Chichester, Wiley.

Lal, P., Lim-Applegate, H. \& Scoccimarro, M. (2001) The adaptive decision-making process as a tool for integrated natural resource management: Focus, attitudes, and approach, Conservation Ecology, 5(2), article 11. DOI: 10.5751/es-00306-050211

Loucks, D. P. \& Gladwell, J. (1999) Sustainability criteria for water resource systems. Cambridge, Cambridge University Press.

Loucks, D. P. \& Beek, van E. (2017) Water resources systems planning and management. An introduction to methods, models and applications. Cham, Springer. DOI: 10.1007/978-3-319-44234-1_1

Mays, L. (2006) Water resources sustainability. New York, McGraw-Hill Professional.

Mencio, A., Folch, A. \& Mas-Pla, J. (2010) Analyzing hydrological sustainability through water balance. Environmental Management, 45(5), pp. 1175-1190. DOI: 10.1007/s00267-010-9461-y

Michael, L. F., Noor, Z. Z., Zardari, H. N. \& Meza, F. J. M. (2013) Analytical hierarchy process application in urban sustainability indicators prioritization. Resources and Environment, 3(5A), pp. 1-5. DOI: 10.5923/s. re.201309.01

Molle, F. (2006) Planning and managing water resources at the river-basin level: Emergence and evolution of a concept. Comprehensive assessment research report 16. Colombo, Sri Lanka, International Water Management Institute. Available at: https://www.iwmi.cgiar.org/assessment/ files_new/publications/CA\%20Research\%20Reports/CARR16.pdf (accessed 7 Feb. 2020).

New York State Department of State (2009) Guidebook: Watershed plans: Protecting and restoring water quality. Available at: https:// www.dos.ny.gov/opd/sser/pdf/WatershedPlansGuidebook.pdf (accessed 7 Mar. 2020)

Oddershede, A., Arias, A. \& Cancino, H. (2007) Rural development decision support using the analytic hierarchy process. Mathematical and Computer Modelling, 46(7-8), pp. 1107-1114. DOI: $10.1016 / \mathrm{j} . \mathrm{mcm} .2007 .03 .006$

Ouyang, Y. (2012) A potential approach for low flow selection in water resource supply and management. Available at: http://dx.doi. org/10.1016/j.jhydrol.2012.05.062 (accessed 7 Mar. 2020).

Räsänen, A., Juhola, S., Monge, M. A., Käkönen, M., Kanninen, M. \& Nygren, A. (2017) Identifying mismatches between institutional perceptions of water-related risk drivers and water management strategies in three river basin areas. Journal of Hydrology, 550, pp. 704-715. DOI: 10.1016/j.jhydrol.2017.05.040

Ruiz-Villaverde, A., González-Gómez, F. \& Picazo-Tadeo, J. A. (2013) Public choice of urban water service management: A multi-criteria approach. International Journal of Water Resources Development, 29(3), pp. 385-399. DOI: 10.1080/07900627.2012.721668 
Saaty, T. L. (1994) How to make a decision: The analytic hierarchy process. Interfaces, 24(6), pp. 19-43. DOI: 10.1287/inte.24.6.19

Shafabakhsh, G., Mirzanamadi, R. \& Mohammadi, M. (2015) Pedestrians' mental satisfaction's relationship with physical characteristics on sidewalks using analytical hierarchy process: Case study of Tehran, Iran. Transportation Letters, 7(3), pp. 121-132.

DOI: 10.1179/1942787514Y.0000000039

Shen, L. Y., Ochoa, J. J., Shah, N. M., \& Zhang, X. (2011) The application of urban sustainability indicators: A comparison between various practices. Habitat International, 35(1), pp. 17-29.

DOI: 10.1016/j.habitatint.2010.03.006

Srinivas, R., Singh, P. A., Dhadse, K., Garg, C. \& Deshmukh, A. (2018) Sustainable management of a river basin by integrating an improved fuzzy based hybridized SWOT model and geo-statistical weighted thematic overlay analysis. Journal of Hydrology, 563 (2018), pp. 92-105. DOI: 10.1016/j.jhydrol.2018.05.059

Tezer, A., Uzun, O., Okay, N. \& Karacor, E. (2018) The importance of identification of Ecosystem-based services on the watershed conservation areas of Melen basin/Duzce. Journal of Kentli: Drinking water basins (Turkish Healthy Cities Association), 30(9), pp. 58-60.

Thapa, B. R., \& Murayama, Y. (2010) Drivers of urban growth in the Kathmandu valley, Nepal: Examining the efficacy of the analytic hierarchy process. Applied Geography, 30, pp. 70-83.

DOI: 10.1016/j.apgeog.2009.10.002

Thomas, J. \& Durham, B. (2003) Integrated water resource management: Looking at the whole picture. Desalination, 156(1-3), pp. 21-28. DOI: $10.1016 /$ S0011-9164(03)00320-5

Thungngern, J., Sriburi, T. \& Wijitkosum, S. (2017) Analytic hierarchy process for stakeholder participation in integrated water resources management. Engineering Journal, 21(7). DOI: 10.4186/ej.2017.21.7.87

Turkey Ministry of Development (2014) National strategy of regional development 2014-2023. Available at: Available at: https://www.turkiye. gov.tr/kalkinma-bakanligi (accessed 7 Mar. 2020).

United Nations (2014) World urbanization prospects: The 2014 revision. New York.

Wani, P., Sreedevi, T. K., Reddy, T. S. V., Venkateswarlu, B. \& Prasad, C. S. (2008) Community watersheds for improved livelihoods through consortium approach in drought prone rain-fed areas. Journal of Hydrological Research and Development, 23, pp. 55-77.

WCED (1987) Our common future. London.

Yang, W., Hyndman, D. W., Winkler, J. A., Viña, A., Deines, J., Lupi, F., et al. (2016) Urban water sustainability: Framework and application. Ecology and Society, 21(4), pp. 4. DOI: 10.5751/ES-08685-210404

Yavuz, F. \& Baycan, T. (2013) Use of SWOT and analytic hierarchy process integration as a participatory decision making tool in watershed management. Procedia Technology, 8, pp. 134-143.

DOI: 10.1016/j.protcy.2013.11.019

Zhou, X., Li, Y. \& Lai, F. (2018) Effects of different water management on absorption and accumulation of selenium in rice. Saudi J Biol Sci, 25(6), pp. 1178-1182. DOI: 10.1016/j.sjbs.2017.10.017 